\title{
Por UMA Didática da História ANTiga No EnSINo SUPERIOR
}

\author{
Fábio Augusto Morales
}

RESUMO: Este artigo visa discutir as implicações ético-políticas e teórico-práticas do ensino de História Antiga em universidades brasileiras atualmente. A discussão está dividida de acordo com cinco variáveis que afetam a elaboração da disciplina: seu lugar nas estruturas de cursos de graduação, seus objetivos, seus objetos, seus métodos e os repertórios de professores e alunos. Argumenta-se que a História Antiga é um lugar estratégico para a reflexão sobre os fundamentos científicos da História, bem como para a crítica de velhas e a proposição de novas narrativas históricas.

PALAVRAS-CHAVE: Ensino de História Antiga; Ensino Superior; História Global.

ABSTRACT: This paper aims to discuss the ethical, political, theorethical and practical implications of teaching Ancient History in contemporary Brazilian universities. The discussion is divided according to five sets of variables that affest the making of the discipline: its place in undergraduate course structures, its aims, its objetcs, its methods and the teachers and students' repertoires. It is argued that Ancient History is a strategical place to reflect on the cientific fundaments of History as well to criticise old and promote new historical narratives.

KEYwORDS: Ancient History teaching; Higher Education; Global History.

Ensinar História Antiga em universidades brasileiras, atualmente, é uma tarefa tão atravessada por impasses que se assemelha a ensinar, digamos, a História do Brasil. Inversão curiosa: se nos primeiros tempos do ensino universitário de História no país, na década de 1940, a História Antiga encontrava-se confortavelmente hospedada na segurança narrativa quadripartite da "História da Civilização" (Idades Antiga, Média, Moderna e Contemporânea), por oposição à "História da Civilização Brasileira" ainda em formação (Silva; Ferreira, 2011), hoje a História Antiga precisa se defender continuamente dos ataques ao seu eurocentrismo e sua eventual inadequação à memória coletiva local ${ }^{2}$, enquanto a História do Brasil assiste, de camarote, as

\footnotetext{
${ }^{1}$ Professor de História Antiga e Arqueologia na Pontifícia Universidade Católica de Campinas; doutor em História Social pela Universidade de São Paulo.

2 Potencializados na discussão recente (e interrompida pelo questionável processo de impeachment de 2016) sobre as Bases Curriculares Nacionais e seu "brasilcentrismo". Uma coletânea abrangente de intervenções sobre o tema foi publicada pela Profa. Dra. Adriene B. Tacla no portal do Dep. de História da UFF (http://www.historia.uff.br/depto/bncc.php); balanços preliminares do debate podem ser encontrados em Moreno (2016) e Silva Junior (2016).
} 
crises das histórias ditas "não brasileiras"3. O objetivo deste texto é tencionar as fronteiras internas e externas elaboradas no processo de periodização historiográfico (em geral) a partir de um lugar específico, a saber, a elaboração de uma disciplina de História Antiga (ou denominações próximas4) em universidades brasileiras. Não busco, aqui, apresentar um diagnóstico do ensino de História Antiga no Brasil recente5, ou mesmo relatar experiências de ensino a partir de "perspectivas inovadoras" por oposição a "abordagens tradicionais" (ainda que a própria organização das críticas aponte para uma direção mais que outras). Menos ambiciosamente, pretendo discutir as variáveis (em suas dimensões ético-políticas e teórico-práticas) que surgem no processo de elaboração da disciplina, cujas escolhas são decisivas para o lugar da História Antiga na universidade. Para tanto, o texto está organizado a partir da discussão de cinco variáveis fundamentais. A primeira é o lugar da disciplina nos cursos de graduação: quando e por quanto tempo, no curso, ela será oferecida? Em qual curso ela será oferecida: História, História/Geografia, Clássicos, História da Arte? A segunda é a definição dos objetivos: o que se quer com e para que serve A História Antiga na universidade brasileira? A terceira é a definição do objeto: o que é História Antiga a ser ensinada, quais são suas fronteiras? A quarta variável envolve os métodos de ensino: como explorar os conteúdos e suas possibilidades no ensino? A quinta variável se relaciona aos repertórios docentes e discentes: como a formação do docente condiciona seus saberes sobre a área e seu ensino? Quem são os alunos, o que trazem e como se relacionam com a gestão da disciplina?

Antes de mais nada, um equívoco deve ser evitado. A discussão crítica

\footnotetext{
3 "Histórias 'não-brasileiras': a antiguidade e o medievo" foi o título dado a uma mesa dos "Diálogos contemporâneos" do $28^{\circ}$. Simpósio Nacional de História, realizado em Florianópolis no ano de 2015, organizado pela Associação Nacional de História (Anpuh). Não está claro se a nacionalidade dos objetos historiográficos se define territorialmente ou espacialmente: historiadores da América portuguesa escreveriam "histórias brasileiras"? Sobre as formas históricas e suas tensões, cf. Guarinello (2003); sobre o lugar da história colonial na "História do Brasil" ou "da América Portuguesa", cf. Novais (1997, p. 17).

4 Tais como "História da Antiguidade", "História da Antiguidade Oriental/Ocidental", "História e historiografia do mundo antigo" etc. As diferentes denominações respondem a diversos fatores, dos quais buscaremos discutir os principais ao longo do texto. Para um levantamento preliminar das denominações das disciplinas relacionadas à História Antiga no Brasil na década de 2000, cf. Regino (2002) e Oliveira (2013, p. 26-28).

5 Falta ainda um estudo exaustivo sobre o tema; de qualquer modo, elementos fundamentais para a história da pesquisa e do ensino de História Antiga são apontados em Faversani (2001b), Regino (2002), Funari (2006), Carvalho e Funari (2007), Funari et al.. (2008), Chevitarese et al. (2008), Garrafoni e Funari (2010), Silva (2010), Silva (2011), Rosa et al.. (2012) e Oliveira (2013).
} 
do ensino de História Antiga em universidades brasileiras não significa, de modo algum, um discurso para sua abolição. Pelo contrário: as variáveis e as eventuais inconsistências das escolhas se apresentam não só para a História Antiga, mas para toda e qualquer disciplina ligada a um período histórico. A seleção de lugares, objetivos, objetos e métodos (na relação entre docentes e alunos concretos) é sempre dramática, e a ênfase em determinados aspectos fatalmente leva à preterição de outros. Assim, as disciplinas de "História do Brasil" devem fazer escolhas tão cruéis quanto as disciplinas de "História Antiga"; a ausência de estudos que se debrucem sobre o ensino universitário de História do Brasil, em si, apenas contribui para a naturalização e fetichização dos processos de formação de períodos pelos historiadores (Guarinello, 2003). Neste sentido, se este texto se volta particularmente para docentes universitários de História Antiga, explorando algumas das inúmeras possibilidades didáticas e suas implicações, por outro ele se pretende um veículo de interlocução no campo da Teoria da História e da Didática-Histórica, território de todos os historiadores ${ }^{6}$.

\section{Os lugares da História Antiga}

No Brasil, as disciplinas de História Antiga estão normalmente vinculadas aos cursos de História, o que é tomado como algo quase natural. No entanto, tal vinculação responde mais às peculiaridades da pesquisa especializada e do ensino universitário no Brasil do que a eventuais lógicas específicas da área. Na Europa e nos Estados Unidos, o controle dos processos de produção documental (em particular via missões arqueológicas7) e a estruturação da pesquisa em grandes áreas em função destes processos (como os "Estudos Clássicos", a "Egiptologia" e a "Assiriologia") estão na base da proximidade da História Antiga com as áreas com as quais partilha fontes, tais como a Filologia, a Arqueologia, as Letras Clássicas e Orientais, a História da Arte, a Filosofia Antiga etc. No Brasil, distantes da produção documental e sem longa tradição institucional de pesquisa especializada em Antiguidade, os

\footnotetext{
${ }^{6}$ Para uma discussão crítica das diferentes abordagens no campo da pesquisa da Didática da História, em particular a relação entre "cultura escolar" e "cultura histórica", cf. Cardoso (2007; 2008). Sobre a Teoria da História e suas relações fronteiras internas e externas, cf. Araújo (2006, 2013) e Malerba (2006).

7 A bibliografia é extensa, mas panoramas e discussões bibliográficas recentes podem ser encontrados em Trigger (2004) e Díaz-Andreau (2007).
} 
pesquisadores de História Antiga normalmente estão alocados em faculdades ou departamentos de História, dialogando de modo mais efetivo com historiadores de outros períodos. O fato da principal associação de História Antiga, o GTHA (Grupo de Trabalho de História Antiga), estar vinculada à Associação Nacional de História é eloquente. O contato com pesquisadores das áreas afins se dá por eventuais projetos e grupos de pesquisa interdisciplinares (em uma ou mais universidades) ou pela participação em eventos da SBEC (Sociedade Brasileira de Estudos Clássicos), que congrega não apenas classicistas, mas também assiriólogos e egiptológos. As vantagens e desvantagens deste arranjo ainda carecem de um estudo aprofundado, mas certamente estão na base (junto da posição periférica no sistema mundial e suas implicações políticas e sociais $\left.{ }^{8}\right)$ de uma eventual especificidade da História Antiga brasileira. Este é o quadro disciplinar de base onde se inserem as disciplinas de História Antiga no Brasil.

A unidade de duração básica dos cursos universitários brasileiros é o semestre, o que inclui um período em média de 15 a 20 semanas de aula (variando em função de feriados e do calendário acadêmico das instituições universitárias). Atualmente, observa-se que as disciplinas voltadas para o campo da "História Antiga" são oferecidas, em geral em um ou dois semestres, e com raras exceções, em três (Oliveira, 2013, p. 26-28). O número de semestres se explica mais em função do campo de forças entre os docentes dos cursos na elaboração dos projetos pedagógicos ${ }^{9}$ do que por equivalências entre um tempo histórico quantitativo e o tempo letivo: o grau de aprofundamento dos saberes docentes em relação a um período (independentemente de sua duração) está diretamente relacionado ao tempo mínimo considerado imprescindível para ensiná-lo e sua legitimidade. Assim, quanto maiores forem os saberes dos docentes sobre a "Antiguidade", mais tempo letivo será dedicado ao período, caso se considere que o ensino universitário destes saberes seja legítimo. $\mathrm{Na}$ produção das "legitimidades historiográficas" entram múltiplos fatores, que vão das representações individuais e coletivas sobre o campo historiográfico nacional e internacional até o mundo dos afetos e seus labirintos. Trata-se, pois, de um embate que se processa no âmbito do campo de forças de cada

\footnotetext{
8 Para uma discussão recente da relação entre perifericidade e historiografia, cf. Santos et al.. (2017).

9 Cuja elaboração, de acordo com a lei 9394/96, art. 14, é de responsabilidade dos profissionais da educação; a universidade conta com ampla autonomia de acordo com o artigo 53 da mesma lei. Cf. a discussão em Felício (2010).
} 
instituição.

A posição da disciplina no curso de graduação dialoga diretamente com as representações docentes sobre o ensino universitário de História. Aqui, duas lógicas diferentes tendem a competir no âmbito dos projetos pedagógicos. Uma, com ênfase na narrativa, dispõe as disciplinas em função de cronologias de base: é o caso da ordenação das disciplinas em função da "História Geral" quadripartite ou da "História do Brasil", sem maiores problematizações sobre a arbitrariedade destas formas (Chesneaux, 1995; Guarinello, 2003). Outra, com ênfase no método, dispõe as disciplinas no curso de acordo com os diferentes graus de complexidade dos procedimentos históricos, abrangendo disciplinas sobre a história da historiografia, sobre os métodos específicos de análise de fontes, sobre as filosofias da História e sobre as implicações sociais da historiografia - no âmbito do que poderíamos tomar como o "campo ampliado" da Teoria da História. Quando oferecer, de acordo com estas diferentes lógicas, a disciplina de História Antiga?

No caso do domínio de uma lógica narrativa em função da "História Geral" quadripartite, a disciplina de História Antiga normalmente é oferecida já no primeiro semestre, vinculada a uma concepção de uma temporalidade linear: a Antiguidade e o Medievo abririam o curso de História antepondo-se ao aparecimento da História do Brasil na Modernidade. Aqui se coloca o problema fundamental do quadripartismo: seu eurocentrismo implícito (Chesneaux, 1995; Guarinello, 2003). Ora, a História Geral não é "geral", na medida em que se estrutura pela narrativa da formação e ascensão da "civilização ocidental", inserindo os demais povos do mundo em função do contato com os europeus. $\mathrm{O}$ processo de criação da atual "História Geral" foi recentemente tratado com detalhe por F. Fillafer (2017). Para o autor, foi na passagem do século XVIII para o XIX que se desenha a solução historicista ao problema da diversidade e desconexão das "histórias particulares" dos diferentes povos do mundo, na construção do que R. Koselleck (2006, p. 41-60) chamou de a História como "coletivo singular". Sem a Bíblia como referência e contra as tentativas comparativistas, os historicistas alemães resolveriam o problema da narrativa (como contar uma História Mundial, se o que há são histórias particulares e dispersas?) por meio da escolha de uma civilização de referência: a europeia. Tal escolha se justificaria (para além do etnocentrismo) pelo fato de que, no século 
XIX, a expansão europeia havia conectado as diferentes histórias do mundo, construindo, assim, polibianamente, a possibilidade de uma história mundial. Desse modo, na equivalência entre historicidade e conectividade, a "civilização europeia" seria a portadora da História e do progresso histórico: os povos do mundo viveriam numa pré-história até que os europeus os integrassem (pelo comércio, pelo império, pelo saber) à História (Fillafer, 2017).

Os processos de descolonização, as lutas por direitos civis e as diferentes formas de globalização após a Segunda Guerra Mundial produziram impactos no mundo acadêmico que ainda são sentidos. A ascensão dos estudos subalternos, dos estudos pós-coloniais, das modernidades múltiplas, das epistemologias do Sul e da mais recente História Global, entre outras abordagens ${ }^{10}$, coloca em xeque os fundamentos eurocêntricos do quadripartismo e das ideologias do "progresso civilizatório". As múltiplas histórias das diferentes sociedades apresentam periodizações próprias que não se enquadram nas "idades" da História Geral e trajetórias que não se coadunam com os valores civilizatórios "ocidentais". Reabre-se, pois, o problema colocado aos historiadores europeus no final do século XVIII, sendo debatido, agora, por historiadores das mais diversas partes do mundo. A História Antiga, neste contexto, apresentada como antecedente narrativo da História Geral, tem que lidar com justificados ataques ao eurocentrismo da narrativa como um todo.

Uma lógica narrativa em função dos períodos da História do Brasil absolveria a graduação em História da acusação de eurocentrismo? Ora, na medida em que a História do Brasil, iniciada normalmente com a invasão portuguesa, é produto e vetor da mesma lógica que preside a estruturação da História Geral eurocêntrica, a resposta nos parece óbvia. Afinal, é o mesmo princípio historicista que orienta esta forma, qual seja, a equivalência entre conectividade (com a Europa) e historicidade (Fillafer, 2017). Tome-se, por exemplo, a questão da posição da História Indígena: antes, durante ou depois das disciplinas de História do Brasil (Almeida, 2009)? Nestas configurações, a disciplina de História Antiga pode ficar "solta" no curso, já que libertada de sua posição narrativa no quadripartismo: oferecida no meio ou no fim do curso, o aluno descobriria que, afinal, houve história antes do Brasil, para além das remissões feitas no início do curso às antiguidades e medievalidades narrativas.

${ }^{10}$ Um balanço recente da abundante bibliografia está em Conrad (2016, p. 17-61). 
O problema central, aqui, é menos a posição da História Antiga e mais a inconsistência da estruturação em torno da História do Brasil. À justificativa identitária, pela qual a opção brasilcêntrica daria conta das demandas locais ("no Brasil, uma história do Brasil"), pode-se argumentar que o local também deve ser problematizado: por que não estruturar a narrativa histórica em função da cidade onde a universidade se localiza, com sua periodização própria? Ou a região? Ou, alternativamente, na medida em que dificilmente as conexões históricas dos "locais" respeitam as fronteiras dos estados nacionais construídos no século XIX (Conrad, 2016), por que não estruturar a narrativa nos termos das histórias globais? O caráter incipiente de uma "grande narrativa global" (Belich et al., 2016) é normalmente usado como justificativa para a manutenção do quadripartismo eurocêntrico, o que se sustenta apenas se se considera que uma lógica narrativa é imprescindível. De qualquer modo, a escolha pelo "Brasil" como unidade estruturante da narrativa reitera os problemas colocados pela História Geral eurocêntrica - então escamoteada, mas não superada.

Já no caso de projetos pedagógicos estruturados por uma lógica com ênfase no método, a História Antiga estaria em pé de igualdade com qualquer outra disciplina ligada a formas historiográficas, da História do Brasil Colonial à História da Eurásia: todas deveriam demonstrar seu potencial como "laboratório da História", tendo como referência a Teoria da História. Adiante discutiremos com mais detalhe este potencial da História Antiga; aqui, de todo modo, vale ressaltar que a configuração atual do ensino superior de História é marcada pela convivência entre estas duas lógicas, a narrativa e metodológica, com clara hegemonia da primeira, apesar de suas inconsistências. Isto não impede que qualquer disciplina "narrativa" abrigue em seus planos uma dimensão metodológica, ou que as disciplinas metodológicas não incorporem estudos de caso ligados às diferentes narrativas; tais diálogos, acredito, são fundamentais. Após décadas de desconstrução das grandes narrativas eurocêntricas e no atual momento de possibilidade da construção de novas narrativas, a naturalização das formas historiográficas (em suas figurações civilizacionais, nacionais ou globais) apenas contribuiria para a irrelevância do discurso histórico; o atual estágio da pesquisa, a crítica interna às formas (a História do Brasil, a História Antiga), feita com o recurso à Teoria da História, é um passo fundamental para sua superação. 
A posição da História Antiga como antecedente na estrutura quadripartite (preliminar em função da História Geral, "solta" porém implícita em função da História do Brasil) ou como laboratório da História tem consequências importantes para o perfil do egresso da graduação em História. Professor, pesquisador, professor-pesquisador? A ênfase no perfil do egresso como professor, recoloca e amplia a questão para as diferentes composições do campo educacional (público e privado) e suas figurações das culturas escolares e das culturas históricas (Cardoso, 2007, 2008; Schmidt, 2012; Carretero; Berger; Grever, 2017). Qual história deve ser ensinada na escola, e como ela deve ser estruturada? A graduação em História - e o ensino de História Antiga - deve se estruturar pelo quadripartismo hegemônico na cultura histórica escolar ${ }^{11}$, ou deve-se preparar o egresso para a atuação crítica em relação a este esquema? A ênfase no perfil do egresso como pesquisador, recoloca o problema do lugar da História Antiga como laboratório da História: como lidar com a diversidade de demandas dos alunos e as diferentes configurações do campo acadêmico historiográfico? A ênfase em uma formação dupla, do egresso como professorpesquisador, recoloca todos os problemas elencados acima de modo ainda mais intenso. De qualquer modo, a vinculação entre a docência e a pesquisa pode ser justamente um dos caminhos para sua superação: nem afastado da produção acadêmica historiográfica, nem apartado dos desafios concretos da produção de narrativas consistentes diante de públicos não-especializados, o professorpesquisador pode repensar, no âmbito de seus projetos específicos e situações concretas, os diferentes lugares da História Antiga12.

\section{História antiga - isto serve, apenas, ao eurocentrismo?}

A segunda variável na elaboração de uma disciplina de História Antiga a ser discutida corresponde aos seus objetivos. O que se quer e para que serve a História Antiga num curso de graduação em História? Múltiplos objetivos são comumente associados à disciplina; aqui, organizaremos a partir de três

\footnotetext{
${ }^{11}$ A cultura escolar normalmente é acessada pela análise dos livros didáticos, parte importante, mas não suficiente, de uma pesquisa didático-histórica; cf. Cardoso, 2007. Sobre a História Antiga nos livros didáticos; cf. Gonçalves (2001), Gonçalves e Silva (2008), Faversani (2001a), Silva (2000, 2001), Silva e Gonçalves (2001), Funari (2001, 2004), Barnabé (2014a, 2014b) 12 Vale mencionar os avanços no âmbito da História Pública para a construção de situações de docência-pesquisa a partir da escola e outras instituições, nas quais o professor-pesquisador elabora e produz conhecimento intimamente vinculado às demandas dos grupos sociais locais; cf. Ashton e Kean (2009), Almeida e Rovai (2011).
} 
grandes funções, definidas seja a partir dos desafios colocados pela crítica ao eurocentrismo, seja a partir das particularidades da formação na área. São elas: a função ocidentalizante, sua contrapartida desocidentalizante, e a função de laboratório da História. Por ocidentalização entendemos a ampla gama de estratégias (narrativas e gráficas, temporais e espaciais) que agem no sentido da naturalização das "identidades ocidentais" nas sociedades periféricas à economia mundial controlada pelos centros capitalistas da Europa ocidental e Estados Unidos, em particular na América Latina (Hall, 1992); para esta função, concorrem o uso da História Antiga como "antecedente narrativo" da estrutura quadripartite da História Geral e/ou como matriz dos elementos culturais distintivos da "identidade ocidental". Por desocidentalização, em contrapartida, entendemos a crítica à naturalização desta identidade ${ }^{13}$, realizada, no âmbito da História Antiga, seja pelo estranhamento das formas culturais até pouco familiares (nas sendas do cultural turn e dos estudos pós-coloniais), seja pela proposição de novas narrativas que, de fato, provincializam a Europa (na tradição neo- ou pós-braudelianas da história global). Vejamos com mais detalhe.

A função ocidentalizante por meio do uso como "antecedente narrativo" da História Antiga se liga, no caso brasileiro, ao quadripartismo da História Geral: a disciplina serve para explicar "o que ocorreu antes" dentro de uma sequência narrativa ligada à História da Civilização, ocupando o lugar de "primeiro" período da História. Neste quadro, a História Antiga se encarregaria da explicação da origem da civilização (fora da Europa, no Egito e Mesopotâmia, mas teleologicamente orientada para a Europa moderna) e suas primeiras conquistas, que seriam refinadas ao longo do tempo para resultarem na modernidade industrial, estatal e científica. A História Antiga, pois, serviria para manter o conforto narrativo de uma "história geral" tão eurocêntrica quanto inconsistente.

Um segundo uso, que também serve à ocidentalização, se liga ao ídolo das origens, criticado por M. Bloch: a História Antiga serviria para explicar as origens de elementos da identidade ocidental. Assim, a Antiguidade especialmente nas formas "Grécia Antiga" e "Roma Antiga" - é figurada ora

13 Para o debate recente sobre ocidentalização/desocidentalização, estudos subalternos e póscoloniais e epistemologias do Sul, cf. Mignolo (2009), Santos e Meneses (2010), Glück (2015). 
como "berço", ora como "aurora" de elementos como o alfabeto, a filosofia, a medicina, o teatro, a democracia, o direito, ou de elementos mais amplos, como a "razão" ou a "política". O desenvolvimento da Egiptologia e da Assiriologia no século XIX adicionou o "Egito antigo" e os "povos mesopotâmicos" na genealogia do estado, da escrita, da arquitetura monumental, sem, contudo, diminuir o lugar da "Antiguidade clássica" como "clássica". A bibliografia já demonstrou as duas principais inconsistências destas figurações, seja a diferença radical entre cada um destes elementos e seus paralelos contemporâneos, seja a desconsideração da história das diferentes reinvenções de cada um destes elementos e de suas articulações em sistemas culturais específicos, tal como demonstrado no campo dos estudos de recepção e usos do passado (Martindale; Thomas, 2006; Kallendorf, 2007; Silva, 2007; Hardwick; Gillespie, 2007; Hardwick; Stray, 2008). Desse modo, a imagem de Atenas como "berço da democracia", por exemplo, se relaciona muito mais com a radical mudança nas representações sobre a democracia clássica elaboradas entre os séculos XVIII e XIX do que com uma eventual continuidade ao longo dos séculos (Brock; Hodkinson, 2000; Wood, 2003, p. 177-204). A Antiguidade, pois, é uma dos reservatórios mais férteis para os usos do passado que a memória coletiva e a história científica eurocêntricas contemporâneas utilizaram para a construção de identidades; ignorar esta clivagem fundamental (assim como as outras, anteriores, que formataram as possibilidades de reinvenção contemporânea) sob a rubrica das "heranças" significa eliminar a alteridade fundante do passado, algo particularmente inadequado em contextos periféricos (do ponto de vista das economias-mundo capitalistas) como Brasil.

A contínua vinculação da História Antiga à função ocidentalizante, para além da história específica de sua constituição, deve ser relacionada à reprodução dos repertórios simbólicos que compõem o capital cultural "classicista" dos segmentos letrados da classe dominante local: o conhecimento (mesmo que superficial) do grego e do latim, a familiaridade tanto com os principais autores e obras dos cânones de diferentes gêneros literários, quanto com as narrativas de momentos emblemáticos da história política antiga (a batalha das Termópilas, a oração fúnebre de Péricles, o assassinato de César etc.), enfim, a fluência no uso de elementos da tradição clássica serviu como um dos elementos para a reprodução da distância social no Brasil, inserindo-se 
assim numa estrutura de longuíssima duração (Guarinello, 2009a). A História Antiga serviria, pois, para distinguir-se (Funari, 1987-8). A inadequação desta função no contexto contemporâneo é (ou deveria ser) evidente em si mesma, em particular diante das intensas transformações culturais associadas seja ao processo (ou devir) da redemocratização do Estado Nacional após o regime militar, seja à ampliação do acesso ao ensino superior operada com maior intensidade a partir da década de 2000. A nova composição da clientela universitária, tanto do ponto de vista socioeconômico quanto regional, exige não apenas uma revisão radical dos usos elitistas da tradição clássica, como também a construção de novas relações desta com as diferentes formas de relação social. Novas soluções, de todo modo, têm sido produzidas no âmbito das ações de extensão universitária relacionadas à tradição clássica (Sumares, 2014; Teodoro et al., 2014), tendo em vista o lugar privilegiado da extensão na interação entre universidade e sociedade: o horizonte é a construção de releituras democráticas da tradição clássica diante das dramáticas transformações da sociedade brasileira contemporânea.

A crise radical do eurocentrismo na segunda metade do século $\mathrm{XX}$, impulsionada pelo desenvolvimento dos estudos pós-coloniais e amplificada pela crítica das identidades no âmbito do cultural turn, levou a uma profunda revisão dos fundamentos eurocêntricos da História Geral, produzida também no âmbito da História Antiga (Webster; Cooper, 1996; Guarinello, 2003). Neste caso, o objeto da disciplina oscila entre uma história disciplinar crítica e um inventário de diferenças e resistências: o ensino de História Antiga funcionaria seja como denúncia da artificialidade do quadripartismo, feita pela crítica dos pressupostos dos historiadores, seja pela ênfase nas diferenças entre o mundo contemporâneo e os supostos "ancestrais antigos", com particular destaque para a dimensão cultural (Silva, 2010). A História Antiga universitária serviria, pois, para demonstrar que a "Antiguidade", por um lado, é uma construção historiográfica continuamente reinventada nos séculos XIX e XX como parte do imperialismo europeu, justificando a ascensão econômica e geopolítica europeia por meio das supostas "heranças clássicas" (a razão, a democracia, o direito), utilizadas como critérios para a hierarquização das sociedades (Horden; Purcell, 2000, Guarinello, 2003; Bernal, 2005); por outro lado, a História Antiga oferece uma enorme quantidade de casos concretos de resistência e contestação 
dos poderes constituídos, das mulheres atenienses que construíam espaços de autonomia (Andrade, 2002) às populações provinciais que criavam formas híbridas de identidade cultural sob o Império Romano (Silva, 2011; Morales, 2014; Bina, 2015), entre muitos outros exemplos (Silva, 2010).

Um segundo uso desocidentalizante da História Antiga, que se apresenta atualmente mais como potência do que como realidade, está diretamente associado a este problema. Após décadas de desconstrução (na chave do cultural turn), os riscos pós-modernos de diluição da cientificidade da História foram suficientes para o aparecimento da demanda por novas narrativas gerais (Armitage, Guldi, 2015; Hunt, 2015). Algumas soluções foram propostas, e a História Antiga tem sido palco de uma interessante fermentação. Uma solução comparativista, por exemplo, foi proposta por M. Hansen ao elencar dezenas de "culturas de cidades-estado", colocando lado a lado as cidades gregas, fenícias, mesoamericanas, suíças e tailandesas (Hansen, 2000; 2002). Apesar de instigante, tal solução não resolve o problema de como articular, temporalmente, estas histórias diversas. Outra solução, de base espacial, foi proposta por P. Horden e N. Purcell (2000): não mais "idade" da História Geral, a História Antiga deveria dar lugar a uma história regionalizada, a História do Mediterrâneo, de caráter ecológico e centrada nas diferentes relações do homem com o meio ambiente - que teria sido constante do Neolítico à Revolução Industrial. Os intensos debates gerados pela obra, que propunha superar o eurocentrismo tradicional, expuseram as fragilidades do projeto original: a inconsistência da unidade, da distinção e mesmo da delimitação da "região", a marginalidade da política, e, acima de tudo, a ahistoricidade da narrativa (Harris, 2011). Não obstante, a "virada mediterrânica" abriu diversas possibilidades de revisão do campo (Morris, 2003; Guarinello, 2003; 2013; Purcell, 2014; Concannon; Mazurek, 2016). Mais eloquente, porém, parece-nos a emergente História Global, que oferece os elementos concretos para uma provincialização da Europa exigida no âmbito dos estudos subalternos e pós-coloniais (Chakrabarty, 2007; Sachsenmaier, 2011; Olstein, 2015; Belich et al., 2016; Conrad, 2016). A História Global, com forte influência dos estudos de história econômica de matriz braudeliana (nas sendas de I. Wallerstein, A. Gunder Frank e G. Arrighi), tem proposto uma forma espacialização da organização narrativa, pela qual os diferentes processos 
históricos são organizados em função de sua extensão espacial (processos sub, semi ou panglobais). Neste contexto, sociedades tradicionalmente alocadas na História Antiga (gregos, persas, egípcios, romanos etc) seriam inseridas nos processos de integração subglobais (a criação de rotas comerciais e o desenvolvimento político em pares de impérios e sistemas políticos na Eurásia ocidental), que orbitam, a partir da Idade do Bronze, os grandes centros localizados na Índia e China (Eurásia oriental; cf. Belich; Darwin; Wickham, 2016, p. 4-5). A caracterização da Grécia clássica como periferia do Império Persa, ele próprio periférico em relação à economia-mundo sino-indiana, é um exemplo eloquente desta "provincialização" (Frank \& Gills, 1993, p. 21-22; Brosius, 2006). Esta parece, do nosso ponto de vista, a função mais interessante que a História Antiga (ou História do Mediterrâneo antigo, ou História da Eurásia ocidental) pode exercer em cursos de graduação brasileiros. O estágio ainda inicial da pesquisa (e a consequente escassez de manuais ou estudos de síntese), mesmo no plano internacional, pode simultaneamente significar um obstáculo e uma oportunidade para o desenvolvimento de perspectivas originais.

Uma terceira função, finalmente, que pode acompanhar tanto os esforços de ocidentalização quanto de desocidentalização, deriva do uso da História Antiga como uma espécie de laboratório da História: a disciplina de História Antiga é um espaço onde as mais diferentes teorias, modelos, abordagens e métodos podem ser testadas, contando com aparatos críticos normalmente abrangentes - em alguns casos, como no problema do uso dos poemas homéricos como fonte histórica, a bibliografia acumulada remonta ao século VI a.C. ${ }^{14}$. O caráter internacionalista e interdisciplinar da História Antiga foi construído ainda sob os influxos da filologia e do antiquarianismo entre os séculos XV e XVIII e rearticulado no âmbito das universidades e escolas superiores nos séculos XIX e XX (Lianeri, 2011). Tal quadro tornou a História Antiga se tornasse uma arena para abordagens produzidas a partir de demandas sociais e intelectuais diferentes, aplicadas a uma quantidade extraordinária de fontes das mais diversas naturezas (literárias, epigráficas ou artefatuais; públicas ou privadas, monumentais ou cotidianas). A diversidade de

${ }_{14}$ Cf. Sobre a recepção antiga de Homero, cf. Graziosi (2008). Para o balanço recente da bibliografia sobre o tema, além da proposição de novas perspectivas, cf. Oliveira $(2012,2015)$ 
experiências sociais documentadas da Antiguidade, reinterpretadas continuamente, habilita a História Antiga a abrigar debates desde a autonomia ou não do "econômico" às representações sobre a sexualidade, da participação política de grupos subalternos à propaganda imperial, do cotidiano burocrático ao cotidiano artesanal etc. Contra ou a favor da ocidentalização, o trabalho morto da História Antiga permite a reflexão sobre a História enquanto ciência a partir de um lugar particularmente diverso, aberto e estruturado.

\section{História Antiga ou Histórias Antigas?}

A discussão das funções se relaciona com outro problema fundamental: afinal, o que é a História Antiga a ser ensinada na universidade? Quais são seus conteúdos? Como estes conteúdos se relacionam (quando se relacionam) entre si? As tensões da História Antiga enquanto forma historiográfica, contornáveis (ainda que com algum desconforto) no âmbito da pesquisa, se apresentam com todos seus abismos na organização de uma disciplina universitária.

Uma primeira escolha diz respeito à natureza dos saberes a serem ensinados. O que é a História Antiga: o conjunto das informações obtidas a partir das fontes produzidas num dado período chamado de "antigo" (assim, "história da Antiguidade"), ou o próprio processo de produção destas informações por uma comunidade profissional (assim, "história da historiografia antiquista")? A escolha de uma ou outra, ou de uma combinação de ambas, é decisiva para a seleção dos conteúdos a serem ensinados: as possibilidades vão de aulas sobre o primeiro período intermediário egípcio a aulas sobre a invenção da egiptologia no século XIX, por exemplo.

Uma segunda escolha se relaciona às unidades de análise para a estruturação da disciplina (Guarinello, 2003). A história a ser ensinada é história do que/de quem: povos, sociedades, grupos sociais, regiões, assentamentos? Assim, definida como "história da Antiguidade", a disciplina pode (tentar) abarcar a história dos "povos antigos": egípcios, sumérios, babilônicos, hebreus, gregos, romanos - ignorando, tanto quanto possível, tanto a exclusão de centenas de outros povos (berberes, dálmatas, trácios, núbios etc) quanto os problemas intermináveis de determinação étnica na interação entre as perspectivas êmicas e éticas. Por exemplo: quais eram os critérios determinantes para a helenidade dos gregos - a ascendência comum, religião, 
língua, admissão aos Jogos Olímpicos, admissão ao Panhellenion, domínio da literatura grega canônica? Os critérios variam com o tempo, espaço e posição social dos sujeitos; a helenidade, enfim, é uma arena em que se negociam admissões e exclusões (Hall, 2001, 2002; Vlassopoulos, 2013). Alternativamente, a história da Antiguidade pode se organizar a partir de "sociedades": mas quais são os contornos de uma sociedade, o assentamento, o tipo de relações sociais e/ou ambientais, as estruturas políticas? Falaríamos de uma sociedade grega (implicando aqui todos os problemas de etnicidade mencionados acima), uma sociedade de cidades-estados (excluindo os gregos que não viviam em pólis), uma sociedade escravista (em função da posição relativa da escravidão na estrutura produtiva e/ou nas representações políticas), ou mesmo uma sociedade baseada em um dado conceito de honra (assim vinculando os contornos de uma sociedade à sua dimensão simbólica) ${ }^{15}$ ? Dado o caráter dinâmico das sociedades e suas relações, quais etnias ou segmentos sociais fazem parte de determinada "sociedade" varia com o tempo, o que traz inúmeros problemas. Uma solução possível seria segmentar a sociedade e produzir histórias de grupos sociais delimitados (os escravos, as mulheres), mas tal segmentação ainda implicaria totalidades nas quais os grupos estariam inseridos, totalidades não menos problemáticas quando não mencionadas. Outra possibilidade seria organizar a história a partir de regiões, e novamente seleções são necessárias: a Grécia e a Itália? Ou todo o Mediterrâneo? Ou o Mediterrâneo e o Oriente Próximo? Uma variante seria organizar a narrativa a partir dos tipos de assentamentos (rurais e/ou urbanos), promovendo uma história das cidades e/ou uma história das aldeias, mas, novamente, tal recorte teria que lidar com a integração destas unidades com as totalidades (sociais ou espaciais) cujos contornos variam com o tempo.

Quando definida em termos de história da historiografia, a disciplina não se exime destas questões. Como estruturar uma história da historiografia (Araújo, 2006)? O que são "historiadores europeus", em uma Europa em processo de (re)invenção no século XIX? Ou "historiografia alemã" antes da unificação? As unidades linguísticas se sobrepõem às condições regionais ou às variadas identidades políticas dos historiadores? Ou há uma entidade abstrata

15 Para a centralidade da pólis na definição da sociedade grega, cf. Hansen; contra, Vlassopoulos (2007); para a escravidão, Ste. Croix (1989), contra Wood (1988; 2003, p. 157-176); para a honra, Lendon (1997). 
como a "comunidade acadêmica", cujas fronteiras seriam nacionais, ou linguísticas, ou políticas, ou teóricas? Como definir as "obras mais influentes"? A ausência de instrumentos de medição do impacto acadêmico (que começam a ser desenhados na atualidade, não sem ambiguidades; Carrizo Sainero, 2000) torna a produção de cenários refém das ressonâncias de determinadas obras nos autores hegemônicos em centros acadêmicos específicos; corre-se o risco de projetar, por exemplo, debates e questões (re)inventadas como centrais no século XX sobre a produção do século XIX, impondo prioridades para autores que discutiam outras questões. A organização de autores em tipologias de abordagens, por sua vez, acaba por enfatizar denominadores comuns que, ainda que reveladores, podem ocultar potências que se encontram justamente nas diferenças ${ }^{16}$.

Uma terceira escolha se relaciona ao problema das fronteiras da História Antiga, que tem sua base mais na organização disciplinar do que em eventuais fundamentos documentais. O que estuda a História Antiga, o "Oriente Próximo Antigo" e/ou a “Antiguidade Clássica”? Se ambas, como relacioná-las em uma narrativa coerente - em particular em disciplinas de duração curta, limitada a um semestre? Tal cisão se funda menos na realidade empírica e mais no desenvolvimento autônomo dos estudos clássicos de um lado e da Egiptologia e da Assiriologia de outro (Carruthers, 2014). A não consideração destes desenvolvimentos autônomos leva a visões essencialistas das "sociedades orientais" e das "sociedades ocidentais", no geral projetando representações sobre a "civilização ocidental” contemporânea sobre os dados empíricos. Assim, por exemplo, "sociedade de corte com autoridade teocrático-despótica com ampla difusão do trabalho forçado" é uma qualificação quase imediatamente aplicável às sociedades orientais da Idade do Bronze, ainda que pudesse, talvez sem grandes dificuldades, ser aplicada à sociedade imperial romana de inícios do primeiro milênio d.C. 17

O problema das fronteiras também se coloca do ponto de vista temporal: quando começa e quando termina a História Antiga? Se o início da

${ }_{16}$ Um exemplo, para fazer uma autocrítica, é a organização de autores de períodos e matizes teóricas diferentes em "seis modelos" em função do lugar dos estrangeiros na democracia e na sociedade ateniense que apresentei em Morales (2015).

17 Sobre o Império Romano como "sociedade de corte", cf. a discussão recente em Paterson (2007), Bang (2011) e Sumi (2011), entre outros. Sobre o culto imperial e suas implicações políticas, cf. a discussão recente em Brodd e Reed (2011) e van Andringa (2016). Sobre a escravidão e as várias formas de trabalho forçado, cf. Bradley e Cartledge (2011). 
"Antiguidade", normalmente associado ao aparecimento do registro escrito dos tributos devidos aos palácios mesopotâmicos, já é particularmente problemático, o termo final do período é objeto de uma intensa disputa entre antiquistas e medievalistas - Antiguidade Tardia (300-800) ou Alta Idade Média, 500-90018? As fronteiras temporais internas não apresentam menores problemas: para além dos debates sobre os critérios de ruptura dos períodos ${ }^{19}$, a produção das formas se dá pela análise de conjuntos documentais com periodizações próprias. Tome-se, por exemplo, o problema da articulação entre periodizações derivadas de estilos cerâmicos, listas epigráficas de governantes, padrões de assentamento, práticas mortuárias, batalhas e guerras etc.; em que medida o "período protogeométrico" corresponderia ao "homérico", "neoassírio" ou à "Idade do Ferro"? Na diacronia as coisas não ficam menos complexas: se os estilos cerâmicos (protogeométrico, geométrico médio, geométrico tardio, orientalizante etc.) são fundamentais para a periodização da Grécia arcaica, no decorrer do período clássico eles cada vez mais são preteridos em função de periodizações de base política (as "épocas" de Temístocles, Péricles, Licurgo etc), como se em determinados momentos a cerâmica, as práticas mortuárias ou os padrões de assentamento deixassem de importar diante das "personalidades" e seus feitos. As formas mais amplas (o período "clássico" da Grécia, "republicano" de Roma, "aquemênida" da Pérsia etc) também impedem a elaboração de períodos que deem conta das diversidades regionais e documentais: os objetos de pesquisa analisados com base em segmentos dos vestígios preservados apresentam ritmos próprios que resistem a sua subordinação à história política ${ }^{20}$. A não consideração dos processos de produção das periodizações (e suas vinculações com os diferentes conjuntos documentais e agendas das comunidades acadêmicas) acaba por naturalizar tais inconsistências.

A solução habitual de mesclar uma estruturação espacial com uma temporal, promovendo assim uma sucessão de tempos e espaços (a narrativa segue uma direção leste-oeste, da origem da escrita na Mesopotâmia às invasões

18 Para os balanços bibliográficos recentes - na perspectiva brasileira - cf. Silva (2008), Silva (2009), Oliveira (2007-2008) e Machado (2015).

${ }_{19}$ Cf., por exemplo, a rediscussão sobre a passagem da República para o Império em Roma em Faversani (2013).

${ }^{20}$ Um exemplo eloquente é a identificação de uma "tradição interna" aos ceramistas áticos produtores de ânforas panatenaicas que se mantem ao longo dos séculos, respondendo mais às alterações nas estruturas físicas dos vasos do que a fatores de ordem política (Francisco, 2012). 
germânicas no Império Romano, em uma "corrida de revezamento" da civilização; Guarinello, 2003), reforçada muitas vezes pela extensão da disciplina por mais de um semestre (no modelo de "História da Antiguidade Oriental" e "História da Antiguidade Ocidental"), não resolve os problemas. Por que transferir o "foco historiográfico" ao longo do tempo para espaços diferentes? Quais sãos os critérios que orientariam tais deslocamentos: os "avanços civilizatórios", o poder? A impossibilidade de responder a tais questões fora de uma chave eurocêntrica ou absolutamente arbitrária faz, normalmente, com que as exclusões sejam simplesmente ignoradas - e, consequentemente, naturalizadas: não se mencionam a Idade do Bronze no Mediterrâneo Ocidental, a Mesopotâmia e o Irã Sassânidas, o mar Negro em qualquer período etc. Para além disso, ignora-se desenvolvimentos que ocorrem, em grande medida, na chave do peer polity interaction (Renfrew; Cherry, 1986; Ma, 2003): a formação dos impérios ateniense e coríntio em meados do século $\mathrm{V}$, dos impérios romano e cartaginês no mesmo período ou, em escala mais ampla, a reconfiguração do Império Romano e o ressurgimento do Império Persa a partir do século I a.C., possibilidades que ainda aguardam um estudo exaustivo.

No caso da definição da disciplina nos termos da história da historiografia, o problema da fronteira se reitera: quais debates, em quais subáreas, tratar ao longo de um ou mais semestres? A história da disciplina é marcada pela especialização não apenas em função dos períodos como também das regiões, e cada subárea apresenta debates autônomos - mesmo quando um debate ultrapassa tais fronteiras, como, por exemplo, a discussão sobre a natureza da economia antiga, os constrangimentos documentais e os ritmos e reviravoltas teóricas específicos das subáreas dão contornos distintos, fazendo com que raramente um historiador se aventure por períodos e regiões distantes de sua zona de conforto (Morris; Manning, 2005).

Uma quarta escolha deve ser feita na definição das relações da História Antiga com as outras disciplinas: quais diálogos interdisciplinares são mais fundamentais para sua organização - com a Arqueologia, a Filologia, a Filosofia, a História da Arte? Tal escolha se reflete não apenas nos conjuntos documentais incorporados nas atividades didáticas, mas também nos conjuntos de questões e debates a serem realizados. Assim, por exemplo, o tratamento da "Grécia Arcaica” a partir de um diálogo mais intenso com a Arqueologia levaria ao 
tratamento mais detido dos assentamentos coloniais (Florenzano, 2010), enquanto que com as Letras Clássicas o que seria imprescindível é a discussão da épica como fontes históricas (Oliveira, 2012). No caso da abordagem da História Antiga como "história da historiografia", tal escolha teria ressonâncias também na seleção dos diálogos interdisciplinares travados ao longo da história da área e suas subáreas: os afastamentos e aproximações com a Arqueologia no estudo da cidade antiga (Guarinello, 2009b), com a História econômica na egiptologia (Moreno Garcia, 2009) etc.

\section{Múltiplos caminhos}

A quinta variável diz respeito à interação entre métodos de ensino, entendidos aqui como o conjunto de estratégias de ensinagem e métodos de avaliação utilizados para a consecução dos objetivos gerais e específicos do oferecimento da disciplina, que apresentam especificidades em relação ao ensino superior (Gil, 2000; Masseto, 2003; Anastasiou; Alves, 2005; Garcia, 2009). As estratégias são múltiplas ${ }^{21}$; aqui, discutiremos as estratégias agrupadas em três conjuntos: a aula, a orientação e o estudo do meio.

Sob o conjunto "aula", incluímos as estratégias associadas à aula expositiva (mais ou menos dialogada) e a discussão de fontes primárias e secundárias em sala de aula. A primeira estratégia certamente é o método mais usual, pelo qual um determinado tema é apresentado aos alunos (com maior ou menor interação) pelo docente durante um determinado período, normalmente estruturada entre a organização do problema historiográfico e o encaminhamento de soluções; pode contar com a síntese de obras ou conjuntos de obras historiográficas ou ainda com segmentos de fontes primárias como meios de exemplificação. Formas mais ou menos dialogadas dependem do tipo de relação estabelecida entre o professor e os alunos, da complexidade dos problemas e da capacidade de tradução destes para o contexto concreto da aula. Tal estratégia tem a vantagem de apresentar um determinado conteúdo de modo sistemático e coerente, indicando aos alunos as referências principais, as fontes primárias mais importantes, os meios de interpretação mais adequados e

\footnotetext{
${ }^{21}$ Anastaiou e Alves (2005, p. 79-99), por exemplo, apresentam o levantamento e a discussão de dezenove estratégias diferentes: aula expositiva dialogada, estudo de texto, portfólio, tempestade cerebral, mapa conceitual, estudo dirigido, lista de discussão virtual, solução de problemas, philips 66, grupo de verbalização/grupo de observação, dramatização, seminário, estudo de caso, júri simulado, simpósio, painel, fórum, oficina e estudo do meio.
} 
as soluções mais consistentes. Mas é justamente nesta vantagem que reside sua desvantagem: a coerência e consistência do conhecimento são mais efeitos da autoridade docente e retórica da aula do que de uma suposta ordem das coisas; cabe ao docente realizar a imprescindível autocrítica das arbitrariedades de suas imprescindíveis seleções.

Já as estratégias de discussão de fontes se dividem em duas grandes possibilidades: a leitura dirigida de fontes primárias e a de fontes secundárias. A discussão de fontes primárias é uma das atividades que mais apontam para o ensino de História como atividade artesanal: aprende-se a ser historiador sendo historiador. No caso da História Antiga, as escolhas de fontes estão associadas a três fatores: a definição mesma de "documento histórico", as diferentes definições das funções e objetos da História Antiga a ser ensinada, e, por fim, a disponibilidade de fontes publicadas material ou virtualmente. Quanto ao primeiro, vale destacar o ainda reinante logocentrismo no ensino superior de História, que produz a quase imediata associação de "documento histórico" a “documento textual” (Meneses, 1983; 1994, p. 17-22). A superação do logocentrismo não pode se limitar ao uso ilustrativo de fontes não-textuais, mas, pelo contrário, deve considerar criticamente os métodos disponíveis (no geral produzidos em áreas vizinhas) para a elaboração de conhecimento histórico a partir das coisas e das imagens (Meneses, 2012; Rede, 2012). Quanto ao segundo fator, é a definição das funções e objetos da História Antiga que informa o que são as fontes primárias: disciplinas que tomem a História Antiga como servindo à ocidentalização, tenderão à adoção das fontes mais canônicas (a oração fúnebre de Péricles, o Pártenon); outras, que tomem a História Antiga como meio para a desocidentalização, poderão adotar como fontes primárias a própria historiografia ocidentalizante (a introdução à História Antiga de $\mathrm{B}$. Niebuhr) ou fontes produzidas por grupos subalternos; outras, ainda, que enfatizem os laços da História Antiga com a Arqueologia, deverão lançar mão de repertórios variados de fontes produzidas nas escavações (da cerâmica às tumbas e às fundações de edifícios). Quanto ao terceiro fator, no que diz respeito à disponibilidade de fontes há atualmente uma mudança importante no quadro. Até o fim do século XX, o acesso às fontes em português era feito ou pelas seleções preparadas por cada docente para seus cursos, ou pelas (poucas) coletâneas publicadas, tais como 100 textos de História Antiga de Jaime Pinsky 
(1972), O Trabalho Compulsório na Antiguidade de Ciro Flamarion Cardoso (1984), ou Antiguidade Clássica de Pedro Paulo Funari (1995). Nas primeiras décadas do século XXI, além da (ainda incipiente) organização de sites e blogs com coletâneas de fontes ${ }^{22}$, um novo universo tem se aberto por conta da multiplicação dos repositórios digitais ou "bancos de teses" (Moreno et al., 2006; Masson, 2008; Shintaku; Vidotti, 2016): dezenas de teses e dissertações são disponibilizadas anualmente, muitas das quais incluem traduções integrais de fontes textuais antigas (em particular na área de Letras) ou catálogos abrangentes de conjuntos de artefatos (em particular na área de Arqueologia).

O uso da discussão de fontes secundárias como recurso didático também é usual, mas a seleção de suas modalidades não escapa de escolhas cruciais. Uma primeira escolha se refere à relação coerência/diversidade: devese adotar um livro-base, que ofereça uma visão abrangente e coerente da Antiguidade (ou da historiografia antiquista), ou deve-se adotar um determinado número de textos (artigos ou capítulos) publicados por diversos autores? Recentemente, a adoção de um livro-base se tornou menos problemática com a publicação da tradução de obras estrangeiras de fôlego e relativamente recentes, como O Antigo Oriente Próximo de M. Liverani (2016, quarta edição de 2011 a partir do original de 1988), a História do mundo grego antigo de F. Lefevre (2013, original de 2007), ou Roma, história de um império de G. Woolf (2017, original de 2012). Em português, um manual coletivo para a história romana (ainda no primeiro volume) está sendo publicado pelo projeto Classica Digitalia da Universidade de Coimbra (Brandão; Oliveira, 2015), enquanto que um manual de História do Mediterrâneo antigo voltado para o ensino superior foi publicado recentemente por N. Guarinello (2013). A coerência que pode ser obtida com a adoção de um livro-base, se, por um lado, oferece bases mais estáveis para os experimentos com as fontes primárias, por outro acaba por limitar a diversidade de interpretações e abordagens derivada da ação de textos variados. De qualquer maneira, a adoção de textos diversos também deve passar por seleções e escolhas importantes: serão lidos os clássicos ou as perspectivas mais atuais? Serão lidos capítulos de livros, no geral

${ }^{22}$ Destaca-se, nesta seara, a iniciativa da Profa. Dra. Juliana Bastos Marques (UNIRIO) de trabalhar sistematicamente, no âmbito da graduação em História, a leitura crítica e edição de artigos da Wikipedia relacionados à História Antiga, o que aponta para novas possibilidades de produção e divulgação de conteúdo científico na área (Marques, 2013; Marques \& Louvem, 2013). 
com visões mais abrangentes, artigos, mais pontuais e afunilados, ou ainda ensaios, a um passo gerais e criativos, porém com poucas referências que permitam a verificação das proposições? Serão lidas obras de autores estrangeiros ou de autores brasileiros? Neste ponto, não apenas as diferentes definições sobre as funções e objetos da História Antiga entram em consideração na tomada de decisões, como também os obstáculos às diferentes trajetórias da área no Brasil e no exterior. Assim, tanto a abundância ou escassez de estudos nacionais quanto a própria definição de quais autores são clássicos passam pela história da formação do campo acadêmico (e editorial) da História Antiga no Brasil.

O segundo conjunto de estratégias é aquele relacionado à orientação de trabalhos ao longo do semestre. As escolhas fundamentais dizem respeito aos modos específicos da orientação, aos produtos finais a serem apresentados e a maior ou menos liberdade na escolha dos temas pelos alunos. Em primeiro lugar, os modos de orientação variam na orientação pelo docente com ou sem monitores, por meio de reuniões presenciais ou contatos virtuais, junto indivíduos ou grupos, durante ou fora do período reservado às aulas - tais escolhas se vinculam tanto às relações entre professor e alunos quanto às condições materiais do trabalho docente em cada instituição. Em segundo lugar, os produtos finais abrangem uma grande possibilidade de formas. De um lado, as diversas modalidades de produção escrita: resenhas de artigos, capítulos de livro ou livros inteiros; projetos de pesquisa com base em fontes primárias e secundárias; artigos acadêmicos; e ensaios - variam os graus de exigência de autonomia e maturidade do aluno para a elaboração de cada produto. De outro lado, as diversas modalidades de apresentação oral ou performática: seminários sobre fontes primárias, fontes secundárias ou sobre temas abertos; júris simulados sobre situações específicas (como, por exemplo, a culpa de Helena na guerra ou a execução dos generais atenienses em 406 a.C.) ou sobre questões mais amplas (primitivistas e modernistas no estudo da economia antiga); dramatizações (com base ou não nas fontes teatrais antigas); painéis, simpósios ou fóruns com apresentações individuais ou coletivas dos trabalhos realizados ao longo do semestre etc. Em terceiro lugar, a maior ou menor liberdade na escolha dos temas é uma escolha crucial que também se apresenta, de resto, na pós-graduação: as pesquisas a serem realizadas pelos alunos devem ser pré- 
determinadas, em função do grau de familiaridade do docente com alguns temas, ou devem ser completamente abertas, em função das demandas dos alunos? É na abertura completa, justamente, um dos momentos em que se apresenta com mais clareza a cultura histórica relacionada à História Antiga: um inventário de temas derivados da elaboração livre seria um medidor extremamente rico para uma análise da recepção da Antiguidade para além de suas manifestações na indústria cultural ou na historiografia, espaços mais tradicionais dos estudos de recepção. De qualquer modo, a escolha da modalidade, mais aberta ou mais fechada, responde ao modo como o docente se relaciona com as condições objetivas e subjetivas da reprodução do ofício: a abertura radical implicaria, para a realização de uma orientação consistente, um considerável tempo dedicado a pesquisar junto dos alunos temas eventualmente distantes de sua especialização; além disso, aos alunos que demonstrem interesse na continuidade da pesquisa para além da graduação, é preciso considerar as possibilidades reais de ingresso em programas com docentes capacitados para uma orientação especializada, o que, novamente, deve considerar a história das virtudes e vicissitudes da organização da área no país.

O terceiro conjunto de estratégias envolve os estudos do meio, que normalmente assumem três formas: visitas a exposições, visitas a sítios arqueológicos e passeios guiados em segmentos do espaço habitado. A primeira modalidade depende da disponibilidade de acervos em instituições que abriguem, de modo permanente ou em exposições itinerantes, artefatos associados à Antiguidade. A variedade de exposições deve ser considerada na formulação das atividades: diferentes lógicas expográficas estruturam diferentes discursos (Meneses, 1994). Assim, por exemplo, exposições itinerantes vinculadas a museus de arte com forte apelo à comunicação de massa e à indústria cultural devem ser incorporadas de modo diferente de exposições organizadas por instituições de pesquisa: o número, tamanho, natureza e estado de conservação das peças selecionadas, a quantidade de informações contextuais nas legendas e painéis, os serviços de educação museológica e a infraestrutura variam em função tanto da história de cada instituição quanto de sua relação com os campos afins (da pesquisa, das políticas culturais, da economia etc.). A segunda modalidade, a visita a sítios arqueológicos, varia em função da proximidade dos campi universitários em relação a sítios que tenham 
práticas estruturadas de educação patrimonial, assim como à própria natureza da escavação, se oriunda de projetos acadêmicos ou vinculadas às práticas de arqueologia de salvamento (Funari; Robrahn-González, 2008). Na medida em que viagens aos sítios mediterrânicos ou médio-orientais demandam um grande investimento, a visita a sítios nacionais pode cumprir uma função tanto de discussão da teoria e dos métodos arqueológicos em geral, quanto de eventuais comparações: pense-se, por exemplo, nas possibilidades de se colocar em paralelo alguns dos gigantescos sambaquis catarinenses (como o Garopaba do Sul, na cidade de Jaguaruna, atualmente com 26 metros de altura e com uma datação de superfície de cerca de 4 mil anos AP; De Blasis et. al., 2007) com um tell médio-oriental como o sítio de Tróia (Zanon, 2008). A terceira modalidade, por fim, os passeios por segmentos do espaço habitado, podem se estruturar a partir de duas lógicas diferentes, mas não-excludentes. A primeira é a discussão sobre as permanências e rupturas de elementos culturais da Antiguidade no espaço contemporâneo, da qual um exemplo eloquente é a recente Breve introdução à arquitetura clássica em São Paulo (Francisco, 2015), elaborado pelo autor a partir de cursos de extensão com estudos do meio realizados junto à Universidade de São Paulo. A segunda é a comparação entre elementos culturais antigos e contemporâneos, tais como os paralelos entre os grafites pompeianos e os grafites e pichações urbanas contemporâneas (Garrafoni, 2017), que contribuem para a relativização e historicização das experiências contemporâneas.

A variedade das estratégias aponta para a arbitrariedade da escolha da aula expositiva como método dominante; de qualquer modo, o equilíbrio entre diferentes estratégias, dentro dos quadros institucionais e materiais de cada instituição, necessariamente, implica na ênfase maior ou menor em diferentes competências e habilidades a serem desenvolvidas.

\section{O ídolo das "bagagens"}

A definição dos objetivos e do objeto da História Antiga estão diretamente relacionadas aos repertórios relativos à área tanto do docente quanto dos discentes. Quanto aos primeiros, é notável nas últimas décadas o maior número de especialistas em História Antiga como docentes da disciplina nas universidades brasileiras públicas, privadas e comunitárias, o que se explica 
tanto pela ampliação dos programas de pós-graduação e pela militância dos especialistas já consolidados para o crescimento da área (Silva, 2011). A formação específica ou não do docente na área é decisiva para o processo de escolha sobre as funções e os objetos de seus cursos, diante dos obstáculos metodológicos e institucionais que demandam anos para serem superados (dos idiomas das fontes primárias e secundárias ao próprio acesso às fontes primárias, no caso das oriundas de escavações). Mesmo no caso dos docentes com formação específica na área, é fundamental que o docente realize o exercício de autocrítica de modo a historicizar sua própria formação, que recebe as marcas, por um lado, das práticas de ensino e pesquisa que experimentou ao longo da graduação e pós-graduação (no Brasil e no exterior), e por outro, dos diálogos teóricos e metodológicos travados ao longo de suas pesquisas. Assim, por exemplo, se a maioria dos pesquisadores de História Antiga (e Arqueologia Clássica) brasileiros passaram direta ou indiretamente (via ex-orientandos) pelos pesquisadores pioneiros estabelecidos, entre as décadas de 60 e 80 , em São Paulo (Eurípides Simões de Paula, Paulo Pereira de Castro, Ulpiano Toledo B. de Meneses, Haiganuch Sarian) ou no Rio de Janeiro (Ciro Flamarion Cardoso, Neyde Thelm), o pertencimento mais ou menos sólidos a determinadas "linhagens" da História Antiga não esgota as trajetórias individuais do pesquisador. De fato, a vinculação às diferentes redes criadas pelos laboratórios e grupos de pesquisa que surgiram nas últimas décadas no país, os períodos de formação nos centros estrangeiros (de estágios curtos a doutorados) e as experiências pessoais as mais diversas são componentes centrais na produção do repertório e das possibilidades do docente na elaboração da disciplina.

Por último, mas não menos importante, a elaboração do plano da disciplina, por outro lado, deve considerar, ainda, o repertório e as demandas dos alunos relacionados à área (Funari, 1987-8). Em condições ideais, um "estudos de público" sobre os conhecimentos prévios dos alunos (Lima, 2014) seria extremamente útil, mas as demandas de tempo e esforço de tal estudo raramente tem lugar diante das exigências práticas da vida universitária. De qualquer modo, é preciso destacar alguns elementos fundamentais na organização da problemática. É preciso considerar a integração entre a cultura escolar e a cultura histórica específica na formação dos repertórios e das 
demandas e possibilidades discentes: desde os conhecimentos prévios relacionados a pontos específicos da disciplina até a diversidade de idiomas dominados, produzidos tanto no âmbito escolar quanto nas diferentes espaços de reprodução da memória social (museus, bibliotecas, meios de comunicação de massa etc.), que formatam os diferentes capitais culturais apresentados pelos alunos. Além da formação prévia, é preciso considerar a cultura escolar específica da universidade onde a disciplina será ministrada: instituições públicas, privadas ou comunitárias, localizadas em regiões economicamente pujantes ou estagnadas, centrais ou periféricas, apresentam diferentes configurações para o estabelecimento das relações entre os diferentes segmentos da comunidade universitária. A escassez de estudos sistemáticos sobre estas questões é eloquente do desequilíbrio, na formação docente, entre conhecimento dos saberes específicos e conhecimento do público com o qual estes saberes serão (re)construídos; tais questões são fundamentais na construção de relações democráticas na universidade, de cuja construção o docente de História Antiga não pode se eximir.

\section{Conclusão}

O presente texto, de modo algo tateante, procurou delinear as principais variáveis que informam a elaboração de uma disciplina de História Antiga no ensino superior brasileiro contemporâneo. $\mathrm{O}$ modelo proposto, baseado em cinco variáveis (lugar, objetivos, objetos, métodos e repertórios docentes e discentes), foi aplicado aqui à História Antiga em função da familiaridade do autor com a bibliografia e a prática específica; no entanto, os dilemas enfrentados pelos docentes de História Antiga brasileiros são comparáveis, em suas variáveis, àqueles enfrentados por qualquer docente de qualquer disciplina ligada a períodos. Neste sentido, longe de constituir mais uma peça no conflito entre "história brasileiras" e "histórias não-brasileiras", procurei com este texto contribuir para a reflexão crítica e sistemática do ensino de História no nível superior a partir de uma perspectiva especializada, que ainda não conta com uma bibliografia numerosa e aprofundada no Brasil. A História Antiga deve continuar sendo ensinada nas universidades brasileiras, não em função da inércia dos rituais de distinção social, mas em virtude de sua potência para a crítica e reconstrução das relações de diferentes grupos da sociedade brasileira 
com o tempo histórico e o espaço mundial.

\section{Agradecimentos}

Agradeço à leitura crítica e às correções dos colegas Alex Degan, Fábio Frizzo, Gustavo Oliveira e Uiran Gebara da Silva; os equívocos, naturalmente, são de minha inteira responsabilidade. 


\section{Referências Bibliográficas}

Almeida, Juniele R. de; Rovai, Marta G. de O. (org). Introdução à História Pública. São Paulo: Letra e Voz, 2011.

Almeida, Maria Regina C. de. O Lugar dos Índios na História entre Múltiplos Usos do Passado: reflexões sobre cultura histórica e cultura política. In: Soihet, Rachel, Almeida, Maria Regina C. de; Azevedo, Cecília; Gontijo, Rebeca. Mitos, projetos e práticas políticas. Memória e historiografia. Rio de Janeiro: Civilização Brasileira, 2009, p. 207-230.

Anastasiou, Léa das G. C.; Alves, Leonir P. Estratégias de ensinagem. In: Anastasiou, Léa das G. C.; Alves, Leonir P. (orgs). Processos de ensinagem na Universidade: pressupostos para as estratégias de trabalho em sala de aula. $5^{\mathrm{a}}$. edição. Joinville-SC: Univille, 2005, p. 67-99.

Andrade, Marta M. de. A Vida Comum: Espaço, Cotidiano e Cidade na Atenas Clássica. Rio de Janeiro: DP\&A, 2002.

Araújo, Valdei L. de. Sobre o lugar da história da historiografia como disciplina autônoma. Revista Locus, Juiz de Fora, v. 12, n. 1, p. 79-94, 2006.

História da historiografia como analítica da historicidade. Revista da História da Historiografia, Ouro Preto, n. 12, p. 34-44, 2013.

Armitage, David; Guldi, Jo. Le retour de la longue durée : une perspective anglo-américaine. Annales. Histoire, Sciences Sociales, Paris, a. 70, n. 2, p. 289318, 2015.

Ashton, Paul; Kean, Hilda (eds). People and their Pasts. Public History Today.

New York: Palgrave Macmillan, 2009.

Bang, Peter F. Court and State in the Roman Empire-Domestication and Tradition in Comparative Perspective. In: Duindan, Jeroen; Artan, Tülay; Kunt, Metin (eds). Royal Courts in Dynastic States and Empires. A Global Perspective. Leiden/Boston: Brill, 2011, p. 103-128.

Barnabé, Luís Ernesto. História antiga e livros didáticos no século XXI: inovações e permanências. Alétheia: Revista de Estudos sobre Antiguidade e Medievo, v. 9, n. 2, p. 31-40, 2014a.

. De olho no presente: História Antiga e livros didáticos no século XXI. OPSIS, Catalão-GO, v. 14, n. 2, p. 114-132, jul./dez. 2014b.

Belich, James; Darwin, John; Frenz, Margaret; Wickham, Chris. The Prospect of Global History. Oxford: Oxford University Press, 2016.

Bernal, Martin. A imagem da Grécia Antiga como uma ferramenta para o colonialismo e para a hegemonia européia. Tradução de Fábio Adriano Hering. In: Funari, Pedro Paulo de A. (Org.). Repensando o Mundo Antigo - Martin Bernal e Laurent Olivier (Textos Didáticos n. 49). Campinas: IFCH/UNICAMP, 2005, p. 13-31.

Bina, Tatiana. A busca pela "originalidade religiosa" nas Gálias no período imperial. Romanitas - Revista de Estudos Grecolatinos, Vitória-ES, n. 5, p. 7892, 2015.

Bradley, Keith; Cartledge, Paul (eds). The Cambridge World History of Slavery. Vol.I: The Ancient Mediterranean World. Cambridge: Cambridge University 
Press, 2011.

Brandão, José Luís; Oliveira, Francisco de. (coords). História de Roma Antiga. Volume 1: das origens à morte de César. Coimbra: Editora da Universidade de Coimbra, 2015. Disponível em: https://digitalis.uc.pt/ptpt/content/livro?id=36908. Acesso em junho de 2017.

Brock, Roger; Hodkinson, Stephen. Introduction: Alternatives to the Democratic Polis. In: Brock, Roger; Hodkinson, Stephen (eds). Alternatives to Athens: Varieties of Political Organization and Community in Ancient Greece. Oxford: Oxford University Press, 2000, p. 1-31.

Brodd, Jeffrey; Reed, Jonathan L. (eds). Rome and Religion: A CrossDisciplinary Dialogue on the Imperial Cult. Atlanta: Society of Biblical Literature, 2011.

Brosius, Maria. The Persians. An Introduction. London: Routledge, 2006.

Cardoso, Ciro F. O trabalho compulsório na Antiguidade: ensaio introdutório e coletânea de fontes primárias. Rio de Janeiro: Graal, 1984.

Cardoso, Oldimar P. A Didática da História e o slogan da formação dos cidadãos. Tese de doutorado, Faculdade de Educação, Universidade de São Paulo, 2007.

- Para uma definição de Didática da História. Revista Brasileira de História, v.28, n.55, p.153-170, 2008.

Carrizo Sainero, G.. Toward a Concept of Bibliometrics, Journal of Spanish Research on Information Science, v.1, n. 2, p. 59-86, 2000.

Carvalho, Margarida M. de; Funari, Pedro Paulo de A. Os avanços da História Antiga no Brasil: algumas ponderações. História, São Paulo, v. 26, n.01, 2007, p. 14-19.

Carretero, Mario; Berger, Stefan; Grever, Maria (eds). Palgrave Handbook of Research in Historical Culture and Education. London: Palgrave Macmillan, 2017.

Carruthers, William (ed). Histories of Egyptology: Interdisciplinary Measures. London: Routledge, 2014.

Chakrabarty, Dipesh. Provincializing Europe: Postcolonial Thought and Historical Difference. Princeton: Princeton University Press, 2000.

Chesneaux, Jean. As armadilhas do quadripartismo histórico. In: Devemos fazer tábula-rasa do passado? Sobre História e historiadores. Tradução de Marcos Silva. São Paulo: Ática, 1995, p. 92-99.

Chevitarese, André L.; Cornelli, Gabriele; Silva, Maria Aparecida de O. (orgs). Tradição Clássica e o Brasil. Brasília: Archai-UnB/Fortium, 2008.

Concannon, Cavan; Mazurek, Lindsay A. (eds). Across the Corrupting Sea: Post-Braudelian Approaches to the Ancient Eastern Mediterranean. London and New York: Routledge, 2016.

Conrad, Sebastian. What is Global History? Princeton/Oxford: Princeton University Press, 2016.

De Blasis, Paulo; Kneip, Andreas; Scheel-Ybert, Rita; Giannini, Paulo César; 
Gaspar, Maria Dulce. Sambaquis e paisagem: dinâmica natural e arqueologia regional no litoral sul do Brasil. Arqueologia Sul-Americana, v. 3, n. 1, p. 29-61, jan. 2007.

De Ste. Coix, Geoffrey E. M. The classe struggle in the Ancient Greek World: from the Archaic Age to the Arab Conquest. Ithaca-NY: Cornell University Press, 1989.

Díaz-Andreau, Margarita. A World History of Nineteenth-Century Archaeology. Nationalism, Colonialism, and the Past. Oxford: Oxford University Press, 2007.

Faversani, F. Ler e escrever: livros didáticos. Hélade, Rio de Janeiro, v. 2, p. 1417, 2001a.

A História Antiga nos Cursos de Graduação em História no Brasil. Hélade, Rio de Janeiro, v. 2, p. 44-50, 2001b.

Entre República e Império: apontamentos sobre a amplitude desta fronteira. Mare Nostrum, São Paulo, n. 4, p. 100-111, 2013.

Felício, Helena Maria dos S. O papel do professor/pesquisador na construção do projeto político pedagógico no Ensino Superior. Olhar de professor, Ponta Grossa-PR, v. 13, n. 1, p. 145-153, 2010.

Fillafer, Franz L. A world connecting? From the Unity of History to Global History. History \& Theory, v. 56, issue 1, p. 3-37, march 2017.

Florenzano, Maria Beatriz B. A origem da pólis: os caminhos da Arqueologia. In: Cornelli, Gabriele (org). Representações da Cidade Antiga: categorias históricas e discursos filosóficos. Coimbra: Imprensa da Universidade de Coimbra, 2010, p. 39-49.

Francisco, Gilberto da S. Panatenaicas: tradição, permanência e derivação. Tese de doutorado. Museu de Arqueologia e Etnologia, Universidade de São Paulo, 2012.

Breve introdução à arquitetura clássica de São Paulo. São Paulo: Cultura Acadêmica, 2015.

Funari, Pedro Paulo de A. Poder, posição, imposição no ensino de História Antiga: da passividade forçada à produção de conhecimento. Revista Brasileira de História, São Paulo, v. 8, n. 15, p. 257-264, set. 1987/fev. 1988.

Antiguidade Clássica: a história e a cultura a partir de documentos. Campinas: Editora da Unicamp, 1995.

. A Importância de uma Abordagem Crítica da História Antiga nos Livros Escolares. Hélade, Rio de Janeiro, v. 2, p. 23-26, 2001.

A renovação da História Antiga. In: Karnal, L. (Org.). História na sala de aula: conceitos, práticas e propostas. São Paulo: Contexto, 2006.

.; Robrahn-González, Erika M. Ética, capitalismo e arqueologia pública no Brasil. História, Franca-SP, v. 27, n. 2, p. 13-30, 2008.

.; Silva, Glaydson José da; Martins, Adilton Luís (orgs). História Antiga: contribuições brasileiras. São Paulo: Annablume, 2008.

Garcia, Joe. Avaliação e aprendizagem na educação superior. Estudos em 
Avaliação Educacional, São Paulo, v. 20, n. 43, p. 201-2013, 2009.

Garrafoni, Renata S.; Funari, Pedro Paulo de A. Considerações sobre o estudo da Antiguidade Clássica no Brasil. Acta Scientiarum. Education, Maringa-PR, v. 32, n. 1, p. 1-6, 2010.

Inscrições, linguagem e diversidade: os grafites de Pompeia e a vida cotidiana no início do Império Romano. Palestra. Universidade de São Paulo, 07 jul 2017.

Gil, Antônio Carlos. O estilo de atuação do professor universitário - uma questão de ênfase. Pensamento \& Realidade, São Paulo, v. 6, p. 39-50, 2000.

Glück, Antje. De-Westernization: key concept paper (Media, Conflict and Democratization. University of Leeds), 2015. Disponível em: http://www.mecodem.eu/wp-content/uploads/2015/05/Glueck-2016_DeWesternisation.pdf. Acesso em: junho de 2016.

Gonçalves, Ana Tereza M. Os Conteúdos de História Antiga nos Livros Didáticos Brasileiros. Hélade, Rio de Janeiro, v. 2, p. 9-13, 2001.

Silva, Gilvan V. da. O ensino de História Antiga nos livros didáticos brasileiros: balanços e perspectivas. In: Chevitarese, André L.; CornellI, Gabriele; Silva, Maria Aparecida de O. (orgs). Tradição Clássica e o Brasil. Brasília: Archai-UnB/Fortium, 2008, p. 21-34.

Graziosi, Barbara. The Ancient Reception of Homer. In: Hardwick, Lorna; Stray, Christopher (eds). A Companion to Classical Receptions. Oxford: Blackwell, 2008, p. 26-37.

Guarinello, Norberto L. Uma morfologia da História: as formas da História Antiga. Politeia, Vitória da Conquista-BA, v. 3, n. 1, p. 41-61, 2003.

Império Romano e Identidade Grega. In: Funari, Pedro Paulo de A.; Silva, Maria Aparecida O. (orgs.). Política e identidades no mundo antigo. São Paulo: Annablume/FAPESP, 2009a, p. 147-161.

Modelos Teóricos sobre a Cidade do Mediterrâneo Antigo. In: Florenzano, Maria Beatriz B.; Hirata, Elaine F. V. Estudos sobre a Cidade Antiga. São Paulo: EDUSP, 2009b.

. História Antiga. São Paulo: Contexto, 2013.

Ensaios de História Antiga. Tese de livre-docência. Faculdade de Filosofia, Letras e Ciências Humanas, Universidade de São Paulo, 2014.

Hall, Jonathan M. Quem eram os gregos. Revista do Museu de Arqueologia e Etnologia, São Paulo, v. 11, p. 213-225, 2001.

Chicago Press, 2002.

. Hellenicity: Between Ethnicity and Culture. Chicago: The University of

Hall, Stuart. The West and the Rest: discourse and power. In: Hall, Stuart; Gieben, Bram (eds). Formations of Modernity. Cambridge: The Open University, 1992, p. 275-320.

Hansen, Mogens H. (ed). A Comparative Study of Thirty City-State Cultures. An Investigation Conducted by the Copenhagen Polis Centre. Copenhagen: The Royal Danish Academy of Sciences and Letters, 2000. 
(ed). A Comparative Study of Six City-State Cultures: An Investigation Conducted by the Copenhagen Polis Centre. Copenhagen: The Royal Danish Academy of Sciences and Letters, 2002.

Hardwick, Lorna; Gillespie, Carol (eds). Classics in Post-Colonial Worlds. Classical Presences. Oxford: Oxford University Press, 2007.

.; Stray, Christopher (eds). A Companion to Classical Receptions. Oxford: Blackwell, 2008.

Harris, William V. O Mediterrâneo e a História Antiga. Tradução de Camila Aline Zanon. Mare Nostrum, São Paulo, n. 2, p. 76-112, 2011.

Horden, Peregrine; Purcell, Nicholas. The Corrupting Sea: A Study of Mediterranean History. Oxford; Malden, MA: Blackwell, 2000.

Hunt, Lynn. Faut-il réinitialiser l'histoire? Annales. Histoire, Sciences Sociales, Paris, a. 70, n. 2, p. 319-325, 2015.

Kallendorf, Craig W. (ed). A Companion to Classical Tradition. Oxford: Blackwell, 2007.

Koselleck, Reinhart. Futuro passado: contribuição à semântica dos tempos históricos. Rio de Janeiro: Contraponto / Ed. da PUC-Rio, 2006.

Lendon, John. E. Empire of Honour. The Art of Government in the Roman World. Oxford: Clarendon Press, 1997.

Lianeri, Alexandra (ed). The Western Time of Ancient History: Historiographical Encounters with the Greek and Roman Pasts. Cambridge: Cambridge University Press, 2011.

Lima, Leilane Patrícia de. A Arqueologia e os indígenas na escola: um estudo de público em Londrina-PR. Tese de doutorado. Museu de Arqueologia e Etnologia, Universidade de São Paulo, 2014.

Ma, John. Peer polity interaction in the Hellenistic Age. Past and Present, v. 180, p. 9-39, 2003.

Machado, C. A antiguidade tardia, a queda do Império romano e o debate sobre o "fim do mundo antigo". Revista de História, n. 173, p. 81-114, jul-dez 2015

Malerba, Jurandir. (org). A história escrita: teoria e história da historiografia. São Paulo: Contexto, 2006.

Marques, Juliana B. Trabalhando com a história romana na Wikipédia: uma experiência em conhecimento colaborativo na universidade. História Hoje, Florianópolis, v. 2, n. 3, p. 329-346, 2013.

.; Louvem, Otávio S. A Wikipédia como diálogo entre universidade e sociedade: uma experiência em extensão universitária. Anais do XIX Workshop de Informática na Escola (WIE 2013), 2013, p. 70-79.

Martindale, Charles; Thomas, Richard F. (eds). Classics and the Uses of Reception. Oxford: Blackwell, 2006.

Masseto, Marcos T. Competência pedagógica do professor universitário. São Paulo: Summus, 2003.

Masson, Silvia M. Os repositórios digitais no âmbito da sociedade informacional. Prisma.com, n. 7, p. 105-152, 2008. 
Meneses, Ulpiano T. B. de. A cultura material no estudo das sociedades antigas. Revista de História, São Paulo, n. 115, p. 103-118, jul/dez 1983.

Do Teatro da Memória ao Laboratório da História: a exposição museológica e o conhecimento histórico. Anais do Museu Paulista, São Paulo, nova série, v. 2, p. 9-42, jan./dez. 1994.

. História e imagem: iconografia/iconologia e além. In: Cardoso, Ciro F.; Vainfas, Ronaldo. (orgs). Novos domínios da História. Rio de Janeiro: Elsevier, 2012, p. 243-262.

Mignolo, Walter. D. Epistemic Disobedience, Independent Thought and DeColonial Freedom. Theory, ulture and Society, v. 26, n. 7-8, p. 1-23, 2009.

Morales, Fábio Augusto. Graecia capta, novamente: considerações sobre os limites da nova romanização da Grécia. Revista do Museu de Arqueologia e Etnologia, Suplemento n. 18, São Paulo, 2014, p. 91-98.

A democracia ateniense pelo avesso: os metecos e a política nos discursos de Lísias. São Paulo: Edusp, 2015.

Moreno, Fernanda P.; Leite, Fernando César L.; Arellano, Miguel Ángel M. Acesso livre a publicações e repositórios digitais em ciência da informação no Brasil. Perspectivas em Ciências da Informação, Belo Horizonte, v. 11, n. 1, p. 82-94, jan./abr. 2006.

Moreno, Jean C. História na Base Nacional Comum Curricular: déjà vu e novos dilemas no século XXI. História \& Ensino, Londrina-PR, v. 22, n. 1, p. 07-27, jan/jul. 2016.

Moreno García, Juan Carlos. From Dracula to Rostovtzeff or the misadventures of economic history in early Egyptology. In: Fitzenreiter, Martin (ed.). Das Ereignis. Geschichtsschreibung zwischen Vorfall und Befund (IBAES, 10). London: Golden House Publications, 2009, p. 175-198.

Morris, Ian. Mediterranization. Mediterranean Historical Review, v 18, p. 30$55,2003$.

.; Manning, John G. Introduction. In: Morris, Ian; Manning, John G. (eds). The Ancient Economy: Evidence and Models. Stanford: Stanford University Press, 2005, p. 1-44.

Novais. Fernando A. Condições de privacidade na Colônia. In: Souza. Laura de Mello e. (org.). História da vida privada no Brasil: cotidiano e vida privada na América portuguesa. São Paulo: Companhia das Letras, 1997, p. 13-39.

Oliveira, Gustavo J. D. Histórias de Homero: um balanço das propostas de datação dos poemas homéricos. Revista História e Cultura, Franca, v.1, n. 2, p. 126-147, 2012.

Tradição épica, circulação da informação e integração cultural nos poemas homéricos. Tese de doutorado. Faculdade de Filosofia, Letras e Ciências Humanas, Universidade de São Paulo, 2015.

Oliveira, Júlio César M. de. O conceito de Antigüidade Tardia e as transformações da cidade antiga: o caso da África do Norte. Revista de Estudos Históricos e Filosóficos da Antiguidade, n. 24, p. 123-135, 2007-2008.

Oliveira, Nairana Z. de. História Antiga no Brasil: um perfil do ensino nas 
universidades brasileiras. Monografia (bacharelado em História). Universidade Federal de Uberlândia, Uberlândia-MG, 2013.

Olstein, Daniel. Thinking History Globally. New York: Palgrave Macmillan, 2015 .

Paterson, Jeremy. Friends in high places: the creation of the court of the Roman emperor. In: SpawfortH, Anthony J. S. (ed). The Court and Court Society in Ancient Monarchies. Cambridge: Cambridge University Press, 2007, p. 121-156.

Pinsky, Jaime. 100 textos de História Antiga. São Paulo: Hucitec, 1972.

Purcell, Nicholas. The Ancient Mediterranean. In: Horden, Peregrine; Kinoshita, Sharon (eds). A Companion to Mediterranean History. West Sussex: Wiley/Blackwell, 2014, p. 59-76.

Rede, Marcelo da S. História e cultura material. In: CARDOSO, Ciro F.; VAINFAS, Ronaldo. (orgs). Novos domínios da História. Rio de Janeiro: Elsevier, 2012, p. 133-150.

Regino, Jonas A. Catálogo dos cursos de História Antiga existentes no Brasil. Relatório técnico (iniciação científica). Universidade Federal de Ouro Preto, Mariana-MG, 2002.

Renfrew, Colin; Cherry, John F. Peer Polity Interaction and Socio-political Change. Cambridge: Cambridge University Press, 1986.

Rosa, Cláudia B.; Marques, Juliana B.; Tacla, Adriene B. Mendes, Norma M. (orgs). A busca do Antigo. Rio de Janeiro: Nau Editora, 2012.

Santos, Boaventura de S.; Meneses, Maria Paula (org). Epistemologias do Sul. São Paulo: Cortez, 2010.

Santos, Pedro Afonso C. dos.; Nicodemo, Thiago L.; Pereira, Matheus Henrique de F. Historiografias periféricas em perspectiva global ou transnacional: eurocentrismo em questão. Revista Estudos Históricos, Rio de Janeiro, v. 30, n. 6o, p. 161-186, 2017.

Sachsenmaier, Dominic. Global Perspectives on Global History: Theories and Approaches in a Connected World. Cambridge: Cambridge University Press, 2011.

Schmidt, Maria Auxiliadora M. dos S. Cultura histórica e cultura escolar: diálogos a partir da Educação Histórica. História Revista, Goiânia, v. 17, n. 1, p. 91-104, jan./jun. 2012.

Shintaku, Milton; Vidotti, Silvana Aparecida B. G. Bibliotecas e repositórios no processo de publicação digital. Biblos: Revista do Instituto de Ciências Humanas e da Informação, Rio Grande-RS, v. 30, n. 1, p. 61-80, 2016.

Silva, Bruno dos S. Romanização e os séculos XX e XXI: a dissolução de um conceito. Mare Nostrum, São Paulo, n. 2, p. 57-75, 2011.

Silva, Glaydson José da. História Antiga e Usos do Passado. Um estudo de apropriações da Antiguidade sob o regime de Vichy (1940-1944). São Paulo: Annablume; Fapesp, 2007.

- Os avanços da História Antiga no Brasil. Anais do XXVI Simpósio Nacional de História - ANPUH, São Paulo, julho 2011, p. 1-31. 
Silva, Gilvan V. da. História Antiga no livro didático: uma parceria nem sempre harmoniosa. Dimensões - Revista de História da UFES, Vitória, n. 11, p. 231238, ju./dez. 2000.

Simplificações e Livro Didático: um estudo a partir dos conteúdos de História Antiga. Hélade, Rio de Janeiro, v. 2, p. 18-22, 2001.

Silva, Gilvan V. da; Gonçalves, Ana Teresa M. Algumas reflexões sobre os conteúdos de História Antiga nos livros didáticos brasileiros. História \& Ensino. Londrina, v. 7, p. 123-142, 2001.

Silva, Marcelo C. Introdução. In: A Realeza Cristã na Alta Idade Média. São Paulo: Alameda, 2008, p. 17-40.

Silva, Norma Lúcia; Ferreira, Marieta de Moraes. Os caminhos da institucionalização do ensino superior de História. História \& Ensino, Londrina-PR, v. 2, n. 17, p. 283-306, jul/dez 2011.

Silva, Semíramis C. Aspectos do Ensino de História Antiga no Brasil: algumas observações. Alétheia: Revista de estudos sobre Antiguidade e Medievo, v. 1, jan/jul 2010, p. 145-155.

Silva, Uiran G. da. A Antiguidade Tardia como Forma da História. Anos 9o, Porto Alegre, v. 16, n. 30, p. 77-108, 2009.

Silva Junior, Astrogildo F. da. BNCC, componentes curriculares de história: perspectivas de superação do eurocentrismo. EccoS - Revista Científica, São Paulo, n. 41, p. 91-106, set./dez. 2016.

Sumares, Gustavo. Nova vida para as línguas mortas. Cultura e extensão (suplemento), São Paulo, v. 11, p. 12-16, 2014.

Sumi, Geoffrey. Ceremony and the Emergence of Court Society in the Augustan Principate. The American Journal of Philology, v. 132, n. 1, p. 81-102, 2011.

Teixeira, Ivana L. Romanidade em Plinio, o Antigo, e a Naturalis História como um 'projeto' político-pedagógico. Tese de doutorado. Faculdade de Filosofia, Letras e Ciências Humanas, Universidade de São Paulo, 2012.

Teodoro, Jenifer; Nery, Renata; Moura, Jean Carlos; Zanirato, Tatiana; Sousa, Fernanda. Experiências de extensão: a Literatura Clássica como forma de unir a sociedade à Universidade. Rónai, v. 2, p. 165-185, 2014.

Trigger, B. História do Pensamento Arqueológico. São Paulo: Odysseus, 2004.

Van Andringa, William. Rhetoric and Divine Honours: On the "Imperial Cult" in the Reigns of Augustus and Constantine. In: Kahlos, Maijastina (ed). Emperors and the Divine - Rome and Its Influence. Helsinki: Helsinki Collegium for Advanced Studies, 2016, p. 10-21.

Vlassopoulos, Kostas. Unthinking the Greek Polis. Ancient Greek History Beyond Eurocentrism. Cambridge/New York: Cambridge University Press, 2007.

Press, 2013.

Greeks and Barbarians. Cambridge/New York: Cambridge University

Webster, Jane; Cooper, Nick (ed). Roman Imperialism: Post-Colonial Perspectives. Leicester: School of Archaeological Studies, 1996. 
Wood, Ellen Meiksins. Peasant-Citizen and Slave: The Foundations of Athenian Democracy. London/New York: Verso, 1988.

Democracia contra o capitalismo: a renovação do materialismo histórico. São Paulo: Boitempo, 2003.

Zanon, Camila Aline. A Ilíada de Homero e a Arqueologia. Dissertação de mestrado. Museu de Arqueologia e Etnologia, Universidade de São Paulo, 2008. 